\title{
Environmental strategies for achieving a new foreign direct investment golden decade in Algeria
}

\author{
Maroua Chaouachi ${ }^{1}$ • Daniel Balsalobre-Lorente ${ }^{2}$ D
}

Received: 16 November 2021 / Accepted: 13 December 2021 / Published online: 23 January 2022

(c) The Author(s), under exclusive licence to Springer-Verlag GmbH Germany, part of Springer Nature 2021

\begin{abstract}
While numerous studies have discussed the impact of economic growth on the environment, this paper advances in the empirical literature, aiming to validate the existence of an N-shaped environmental Kuznets curve (EKC) relationship between the ecological footprint and economic growth in Algeria during the period 1975-2014. The proposed empirical model includes as additional explanatory variables the foreign direct investment (FDI) and the electricity consumption aimed to increase the relevance of the results, correcting the lack of studies that have previously analyzed the EKC for the case of Algeria. Through the ARDL econometric approach, we confirm an N-shaped EKC between the per capita economic growth and ecological footprint in Algeria, reinforcing these results using the FMOLS and DOLS techniques. In the long run, the empirical results confirmed that the N-shaped EKC in Algeria is valid; electricity consumption and foreign direct investment directly impact ecological footprint. Even though the main objective of this study is to assess the $\mathrm{N}$-shaped EKC, the novelty of the paper is the analysis of the interaction between FDI and electricity consumption. The empirical evidence reveals that FDI contributes to reducing the negative impact of fossil sources in the energy mix in Algeria through the transition to a cleaner energy mix pattern. In the final step of our analysis, we explore the causal nexus among variables by applying the Toda Yamamoto non-causality test. The Toda Yamamoto non-causality test reveals a unidirectional causality between economic growth and ecological footprint; one-run relationship flows from electricity consumption to ecological footprint, and economic growth leads to cause foreign-direct investment. These empirical results evidence the necessity of establishing suitable policies after the gold decade of the FDI in Algeria, being required to advance in this line to come back to ascending levels of FDI after the financial crisis of 2008 and the current COVID-19 crisis. In this sense, policymakers should consider the advantages of FDI for promoting clean foreign investment, necessary for reaching a transition to sustainable development in Algeria. In this sense, this study proposes a battery of environmental strategies to achieve this objective and sustainable growth in the country. Thus, policy implications and directions for future research are suggested.
\end{abstract}

Keywords Algeria $\cdot$ Environmental quality $\cdot$ EKC $\cdot$ FDI $\cdot$ Ecological footprint

\section{Introduction}

Between 2006 and 2011, Algeria experimented with a golden era of FDI, which found inflows average $\$ 2.25 \mathrm{bn}$ annually (UNCTAD 2020). After that period, investment

Responsible Editor: Nicholas Apergis

Daniel Balsalobre-Lorente

Daniel.Balsalobre@uclm.es

Maroua Chaouachi

marwa_ch@yahoo.fr

1 Higher Institute of Management, University of Tunis, Tunis, Tunisia

2 University of Castilla-La Mancha, Cuenca, Spain dropped to about $\$ 1.1$ bn a year, not recovering well from the 2008 financial crisis. In addition, the government restrictions on foreign investors, as part of a policy of economic nationalism pushed forward after 2008 (IMF 2020), is positioned 157th out of 190 countries in the World Bank (2019). Nowadays, Algerian law limits a foreign investor's stake in a local firm to $49 \%$ and requires foreign bidders for state contracts to find local partners. Corruption, a weak financial sector, and legal insecurity regarding intellectual 
property rights are relevant barriers to investment in Algeria. Consequently, even FDI will imply a transition from selfconstrained economies (Gygli et al. 2019). This process also directly impacts environmental pressure (Ansari et al. 2020; Shahbaz et al. 2020).

By contrast, the ascending levels of FDI can impulse the technological transference necessary for sustainable development (Rudolph and Figge 2017; Álvarez-Herranz et al. 2017; Aziz et al. 2020). So, foreign investments can accelerate the transition to sustainable economic growth based on implementing high-tech industry in the host country.

Although air pollution is a severe problem in Algeria, the desertification process is the leading ecological trouble of Algeria, being necessary active policies for correcting this process, where the ecological footprint analysis is essential for this aim. In addition, the increased pressure on the ecological footprint results from increased demand for consumption and usage associated with economic growth, trade expansion, and globalization (Ansari et al. 2020).

Some researchers have debated the impact of environmental degradation on national economic growth (Sarkodie and Strezov 2019; Boufateh and Saadaoui 2020; Ike et al. 2020), confirming that, in the long run, economic growth implies ascending demand for environmental quality (Lacheheb et al. 2015; Xu et al. 2020). Hence, the N-shaped EKC empirical evidence (Álvarez-Herranz et al. 2017; Balsalobre-Lorente et al. 2018; Ekeocha 2021) admits the return to an ascending environmental pressure after a certain income level is achieved. This paper advances in the empirical literature, establishing the existence of an $\mathrm{N}$-shaped linkage between economic growth and ecological footprint (Bekun et al. 2021; Naqvi et al. 2021; Gyamfi et al. 2021). Remarkably, this study is novel in the context of Algeria, covering the period 1975-2014.

To our understanding, this is the first study that applied in the long run by using ARDL and the FMOLS and DOLS cointegration techniques in the context $\mathrm{N}$-shaped EKC hypothesis for Algeria to explain alternative influences of shocks on the ecological footprint.

As a result of the absence of agreement and results of previous studies, this study explores the impact of income, FDI, and electricity consumption on the progress of environmental quality, analyzing the association between ecological footprint and FDI. We assume that pollution hypotheses (pollution halo or pollution havens) are valid in Algeria and practically useful for further policy consideration relating to sustainable development. Thus, the current study contributes to the empirical literature exploring the interaction between FDI and electricity consumption on the ecological footprint and how it is necessary to promote high-tech and eco-friendly industries in Algeria.

In the instance of Algeria, we utilized the ARDL model. We discovered evidence for an $\mathrm{N}$-shaped connection between per capita income and ecological footprint, confirming our hypothesis of an N-shaped EKC. The empirical results, presented by different econometric techniques, validate the $\mathrm{N}$-shaped EKC relationship for Algeria. The empirical analysis also includes additional explanatory variables, electricity consumption, and FDI, as a proxy of globalization, which offers exciting policy implications, covering previous literature gaps.

The remaining parts of the study are ordered: "Literature review" reviews the studies on empirical and theoretical issues. "Data and methodology" presents the data description, the econometric model, and the methodologies applied. "Empirical results" contains the analytical findings and discussion. The final section offers conclusions and policy directions.

\section{Literature review}

The seminal study of Grossman and Krueger (1991) concluded that environmental degradation increases with per capita income to a certain level. After this turning point, economies experiment with an environmental correction process. The N-shaped environmental Kuznets curve indicates that the traditional EKC theory will fail the test time, considering that in the long run, ascending income levels will generate ascending environmental pressure, mainly as a consequence of technical obsolescence (Álvarez-Herranz et al. 2017; Balsalobre-Lorente et al. 2018). Balsalobre-Lorente et al. (2018) postulated that the N-shaped relationship arises if the scale effect overcomes both the composition and the technical effect due to an inadequate regulation for improving technological advances. For the case of Algeria, Wang and Dong (2019) and Génesis-Carolina et al. (2021) validated the EKC between economic growth and the ecological footprint in Algeria. Latifa et al. (2014) confirmed the U-inverted EKC for Algeria between $\mathrm{CO}_{2}$ emissions and GDP both in the short and long term. Bouznit and PabloRomero (2016) explored the linkage between carbon emissions and economic growth in Algeria, taking into account energy use, electricity consumption, and trade openness. The study of Layachi (2019) confirmed that economic growth has a positive and significant impact on carbon emission in Algeria.

The link between economic growth, FDI, and ecological footprint is contentious with many competing viewpoints. Different studies have assessed the impact of FDI on environmental degradation (Qian and He 2010; Du and Zhang 2018; Ahmed et al. 2019; Sabir and Gorus 2019; Yilanci and Gorus 2020; Kirikkaleli et al. 2021). Yilanci and Gorus (2020) concluded that globalization directly impacts the ecological footprint in the MENA area for 1981-2016. Similarly, Du and Zhang (2018) discovered an N-shaped 
relationship between economic growth and $\mathrm{CO}_{2}$ emissions in China. Sabir and Gorus (2019) applied the ARDL method to investigate how economic globalization influences the ecological footprint. In the long run, their finding confirmed that economic globalization harms the environmental footprint in the ASIAN region, establishing the EKC and a nonlinear linkage between globalization and the ecological footprint. Ansari et al. (2021) confirmed a negative connection between FDI, renewable energy, and the ecological footprint. Aziz et al. (2020) examined the link between globalization and environmental degradation in MINT nations from 1995 to 2018 , showing that globalization and carbon emissions presented an inverted U-shaped linkage, offering evidence of a transition to a high-tech pattern in the region.

Few studies have assessed the impact of foreign direct investment on ecological footprint as a proxy of environmental degradation. From 44 member countries of the Belt and Road Initiative, Liu and Kim (2018) showed that FDI inflows improve the total ecological footprint. In a study in the USA from 1970 to 2015, Zafar et al. (2019) opined that FDI inflows help curtail ecological footprint. Moreover, Balsalobre-Lorente et al. (2019) confirmed an invertedU-shaped association between FDI inflows and ecological footprints for MINT countries (Mexico, Indonesia, Nigeria, and Turkey) from 1990 to 2013. They found that although FDI initially leads to environmental degradation, the impact reverse beyond a certain level of FDI.

In contrast to previous research findings, Destek and Okumus (2019) looked at the pollution haven hypothesis (PHH) in 10 newly industrialized economies over the period 1982-2013. According to their results, the environmental footprint tends to decline at lower degrees of foreign-direct investment. Instead, this effect does not continue at a higher level of FDI, resulting in a U-shaped relationship. Recently, Chowdhury et al. (2021) investigated the impact of FDI inflows on the ecological footprints of 92 countries in the period 2001-2016. Their findings reveal that the FDI is positively associated with the ecological footprint. Similarly, Yin and Hussein (2021) assessed the factors that influence ecological footprint in 5 Southeast Asian countries and discovered that FDI inflows positively contribute to environmental quality.

Different studies have explored the link between electricity consumption and the ecological footprint for Algeria (Akrour et al. 2021; Sahnoune et al. 2013; Rahmane et al. 2021; Belaid and Youssef 2017). For example, Rahmane et al. (2021) concluded that policymakers should enhance investment in renewable energy and control the overexploitation of fossil energy, which reduces emissions and preserves the environment. Belaid and Youssef (2017) concluded that renewable electricity consumption could reduce environmental pressure in Algeria. But so far, clean electricity generation has not moved forward to a developed level that allows a substantial contribution to the energy-based emissions reduction target.

Our study fills the gap in past literature, analyzing the association between the connection of electricity consumption and FDI on the ecological footprint in Algeria. Hence, it is necessary to examine the role of FDI as a proxy globalization process and how it impacts the ecological footprint through changes in the energy pattern.

This research advances in analyzing the long-term connection between economic growth, FDI, energy usage, and ecological footprint in Algeria between 1975 and 2014. To this end, we consider an N-shaped EKC pattern, introducing the interaction between FDI and energy usage, where the transition to a developed stage depends on proper regulations to solve the technical obsolescence.

\section{Data and methodology}

As we have explained above, the current study aims to assess the N-shaped EKC hypothesis between economic growth per capita (LGDPP) and ecological footprint per capita (LEFP) in Algeria for the period 1975-2014 (according to data availability). Through the ARDL approach, as the main empirical technique, we also investigate the nexus between electricity consumption (LELE), foreign direct investment (LFDI), and ecological footprint per capita (LEFP), as well as the interaction between the electricity consumption and the foreign direct investment (LFDI*LELE). We included yearly data from the World Bank database (2021) for economic growth per capita, electricity consumption, and foreign direct investment and the Global Footprint Network (2021) for the ecological footprint in Algeria. For deleting heterogeneity, the variables were transformed into a natural logarithm for ensuring that series were normally distributed (Kirikkaleli et al. 2020; Rjoub et al. 2021).

The variables utilized in this study are listed in Table 1.

The following Eq. 1 reveals the proposed model:

$$
\begin{aligned}
L E F P_{t} & =\beta_{0}+\beta_{1}(L G D P P)_{t}+\beta_{2}(L G D P P)_{t}^{2}+\beta_{3}(L G D P P)_{t}^{3} \\
& +\beta_{4}(L E L E)_{t}+\beta_{5}(L F D I)_{t}+\beta_{6}(L E L E * L F D I)_{t}+\varepsilon_{i t}
\end{aligned}
$$

where LEFP is the natural logarithmic transformation of ecological footprint per capita, and it is used as a proxy for environmental degradation (Ulucak and Bilgili 2018; Hassan et al. 2019). LGDPP, LELE, and LFDI are the natural logarithms of GDP per capita, electricity consumption, and foreign direct investment. In accordance with previous literature (Álvarez-Herranz and BalsalobreLorente 2015; Álvarez-Herranz and Balsalobre Lorente 2016; BalsalobreLorente et al. 2018), $L G D P P^{2}$ explores if a high level of GDP may contribute to the alleviation of ecological problems, the LGDPP $^{3}$ refers to the cubic of economic growth 
Table 1 Variable description

\begin{tabular}{lllc}
\hline Variables & Symbols & Definitions & Sources \\
\hline Ecological footprint & LEFP & Ecological footprint per capita & Global \\
& & & Footprint \\
& & & Network \\
Economics growth per capita & LGDPP & Constant 2010 USD & WDI(2021) \\
Electricity consumption & LELE & Kwpc & WDI(2021) \\
Foreign direct investment & LFDI & Net inflows & WDI(2021) \\
\hline
\end{tabular}

per capita and the return to an ascending pollution pattern (Dogan and Inglesi-Lotz 2020), $\varepsilon$ is the error term, $\beta_{1}, \beta_{2}$, $\beta_{3}, \beta_{4}, \beta_{5}, \beta_{6}$ denote parameters, and $t$ represents the time. Depending on the sign of the coefficients of exogenous variables related to GDPP, the EKC will assume various shapes ${ }^{1}$ (Balsalobre-Lorente and Álvarez-herranz 2016)

\section{Unit root tests}

Before embarking on the econometric analysis, the stationary of each variable ought to be checked through the traditional ADF (Dickey and Fuller 1979) and PP (Phillips and Perron 1988) unit root tests (see Table 2) to establish the order of integration of all series.

\section{Cointegration tests}

Once we have confirmed the stochastic properties of the selected variables, it is necessary to explore the long-run properties of selected variables, checking the traditional Fisher-Johansen cointegration test (1991). The equation examining the null hypothesis for the Fisher-Johansen cointegration test is denoted as follows:

$-2 \sum_{i=1}^{N} \log \left(\Pi_{i}\right) \rightarrow \chi^{2} 2 N$

$\chi^{2}$ values are built on MacKinnon et al. (1999), and $p$-values are stated for Johansen's cointegration trace and maximum eigenvalue tests.

In a second phase of the cointegration analysis, we apply Bayer and Hanck (2013) combined test to cointegrate the

\footnotetext{
$\overline{1}$ If $\beta_{1}=\beta_{2}=\beta_{3}=0$, no Kuznets relationship between environmental degradation and economic growth.

If $\beta_{1}>0$ and $\beta_{2}=\beta_{3}=0$, increasing in GDPP leads to environmental deterioration.

If $\beta_{1}<0$ and $\beta_{2}=\beta_{3}=0$, decreasing in GDPP leads to environmental deterioration.

If $\beta_{1}<0$ and $\beta_{2}>0$ and $\beta_{3}=0$, a U-shaped EKC is found.

If $\beta_{1}>0$ and $\beta_{2}<0$ and $\beta_{3}=0$, an inverted $\mathrm{U}$-shaped EKC is found.

If $\beta_{1}>0$ and $\beta_{2}<0$ and $\beta_{3}>0$, it represents a cubic polynomial or $\mathrm{N}$-shaped EKC.

If $\beta_{1}<0$ and $\beta_{2}>0$ and $\beta_{3}<0$, it represents an inverted $\mathrm{N}$-shaped EKC between environmental degradation and economic growth.
}

Table 2 Main statistics and correlation

\begin{tabular}{|c|c|c|c|c|}
\hline & LEFP & LGDPP & LELE & LFDI \\
\hline Mean & -0.2358 & 8.2359 & 6.3525 & 16.8603 \\
\hline Median & -0.3147 & 8.2104 & 6.3276 & 19.2114 \\
\hline Maximum & 0.4054 & 8.4557 & 7.2173 & 21.7337 \\
\hline Minimum & -0.8675 & 8.0470 & 5.2765 & -17.7964 \\
\hline Std. Dev. & 0.3267 & 0.1172 & 0.4765 & 6.95189 \\
\hline Skewness & 0.3068 & 0.3636 & -0.2878 & -3.3638 \\
\hline Kurtosis & 2.4851 & 1.9830 & 2.6880 & 16.6459 \\
\hline Jarque-Bera & 1.0694 & 2.6054 & 0.7144 & 385.7908 \\
\hline Probability & 0.5858 & 0.2717 & 0.69960 & 0.0000 \\
\hline Sum & -9.4358 & 329.43 & 254.1031 & 674.4138 \\
\hline Sum Sq. Dev. & 4.1638 & 0.5359 & 8.8586 & 1884.8260 \\
\hline \multicolumn{5}{|c|}{ Correlation matrix } \\
\hline & LEFP & LGDPP & LELE & LFDI \\
\hline LEFP & 1.0000 & & & \\
\hline LGDPP & $\begin{array}{l}0.8344 * * \\
(0.0000)\end{array}$ & 1.0000 & & \\
\hline LELE & $\begin{array}{l}0.9648 * * \\
(0.0000)\end{array}$ & $\begin{array}{l}0.7299 * * \\
(0.0000)\end{array}$ & 1.0000 & \\
\hline LFDI & $\begin{array}{l}0.3839 * * \\
(0.0000)\end{array}$ & $\begin{array}{l}0.3217 * * \\
(0.0429)\end{array}$ & $\begin{array}{l}0.3094 * \\
(0.0521)\end{array}$ & 1.0000 \\
\hline
\end{tabular}

$* p<10 \% ; * * p<5 \% ; * * p<1 \%$

analytic variables $L G D P P, L E L E, L F D I$, and $L E F P$. This recently revised cointegration approach incorporates the results of several independent tests, including tests of Engle and Granger (1987), Johansen (1991), Boswijk (1994), and Banerjee et al. (1998), and provide a more comprehensive result. The formula proposed by Bayer and Hanck (2013) is as follows:

$E G-J=-2(\operatorname{Ln}(p E G)+\operatorname{Ln}(p J))$
$E G-J-B o-B D M=-2(\operatorname{Ln}(p E G)+\operatorname{Ln}(p J)+\operatorname{Ln}(p B o)+\operatorname{Ln}(p B D M))$

Fisher's statistics are used to see if the underlying variables are cointegrated, where $p E G, p J, p B o$, and $p B D M$ denote the $p$-values of cointegration tests of Engle and Granger (1987), Johansen (1991), Boswijk (1994), and Banerjee et al. (1998), respectively. When it is more than 
the critical values, we can reject the null hypothesis of no cointegration (Bayer and Hanck 2013).

\section{Econometric techniques}

In addition, to emphasize the cointegration among the variables, we apply the auto-regressive distributed lag (ARDL) model (Pesaran et al. 2001). The ARDL is allowed when series are mixed either $I(0)$ or $I(1)$ and none of them is $I(2)$ since the presence of the $I(2)$ component makes null and void the predicted $F$-stat for estimating cointegration (Ouattara 2004; Adebayo and Demet 2020). This technique requires suitable lag selection, and a suitable lag length may solve the endogeneity's problem. Likewise, this approach accommodates a limited sample size (Kirikkaleli et al. 2018; Ayobamiji and Kalmaz 2020; Adebayo and Kirikkaleli 2021). Besides, it is beneficial because it simultaneously generates the short- and long-run relationship (Pesaran et al. 2001; Nazir et al. 2018). This process empathizes the formulated policy of this study to be efficient. If the variables series are stationary at the first and second differences, the ARDL can be used independently (Obobisa et al. 2021; Gill et al. 2018). The symmetric relationship between variables is summarized as shown below:

$$
\begin{aligned}
\Delta \text { LEFP }_{t} & =\omega_{0}+\omega_{1}(L E F P)_{t-1}+\omega_{2}(L G D P P)_{t-1} \\
& +\omega_{3}(L G D P P)^{2}{ }_{t-1}+\omega_{4}(L G D P P)^{3}{ }_{t-1} \\
& +\omega_{5}(L E L E)_{t-1}+\omega_{6}(L F D I)_{t-1}+\omega_{7}(L E L E * L F D I)_{t-1} \\
& +\sum_{j=1}^{t} \varphi_{1} \Delta(L E F P)_{t-j}+\sum_{j=1}^{t} \varphi_{2} \Delta(L G D P P)_{t-j} \\
& +\sum_{j=1}^{t} \varphi_{3} \Delta(L G D P P)^{2}{ }_{t-j}+\sum_{j=1}^{t} \varphi_{4} \Delta(L G D P P)^{3}{ }_{t-j} \\
& +\sum_{j=1}^{t} \varphi_{5} \Delta(L E L E)_{t-j}+\sum_{j=1}^{t} \varphi_{6} \Delta(L F D I)_{t-j} \\
& ++\sum_{j=1}^{t} \varphi_{7} \Delta(L E L E * L F D I)_{t-j}+\mu_{t}
\end{aligned}
$$

where $\omega_{0}$ is the drift constant, $\omega_{1}, \omega_{2}, \omega_{3}, \omega_{4}, \omega_{5}, \omega_{6}, \omega_{7}$ are the long-run multipliers, whereas the remaining expressions with summation sign $\varphi_{1}, \varphi_{2}, \varphi_{3}, \varphi_{4}, \varphi_{5}, \varphi_{6}, \varphi_{7}$ represent the short-run dynamics, $t$ is the lag length based on Akaike information criterion (AIC), $\Delta$ and $\mu_{t}$ represent the first difference operator and the white noise component, respectively.

With the next hypotheses, the existence of cointegration is tested using $F$-test statistics:

$$
\begin{aligned}
& H_{0}: \omega_{0}=\omega_{1}=\omega_{2}=\omega_{3}=\omega_{4}=\omega_{5}=\omega_{6}=0 \\
& H_{1}: \omega_{0}=\omega_{1} \neq \omega_{2} \neq \omega_{3} \neq \omega_{4} \neq \omega_{5} \neq \omega_{6} \neq 0
\end{aligned}
$$

The variables are cointegrated if the $F$-statistics exceed Pesaran critical values' upper boundary at 5\% (Pesaran et al. 2001). The critical values are presented for any number of predictors, every sample size, and the estimated model's shortrun coefficients. The decision-making process is facilitated by the $p$-values generated for both $T$ and $F$-statistics. We use the most reliable and recent set of crucial values to provide reliable estimations for a limited number of observations.

By considering an error correction model (ECM) for Eq. 5 into our short run, the following equation would present coefficients of the ARDL model:

$$
\begin{aligned}
\Delta \text { LEFP }_{t} & =\omega_{0}+\sum_{j=1}^{t} \theta_{1} \Delta(\text { LEFP })_{t-j}+\sum_{j=1}^{t} \theta_{2} \Delta(L G D P P)_{t-j} \\
& +\sum_{j=1}^{t} \theta_{3} \Delta(L G D P P)^{2}{ }_{t-j}+\sum_{j=1}^{t} \theta_{4} \Delta(L G D P P)^{3}{ }_{t-j} \\
& +\sum_{j=1}^{t} \theta_{5} \Delta(L E L E)_{t-j}+\sum_{j=1}^{t} \theta_{6} \Delta(L F D I)_{t-j} \\
& ++\sum_{j=1}^{t} \theta_{7} \Delta(L E L E * L F D I)_{t-j}+\delta E C T_{t-j}+\mu_{t}
\end{aligned}
$$

where $\theta_{i}(i=1 \ldots 7)$ denotes the short run's parameters of variables, $E C T_{t-j}$ denotes the error correction, which displays the adjustment o speed from short run's shock to the long-run balance, $\delta$ represents the parameter for $E C T_{t-j}$.

Furthermore, we run a series of diagnostic tests to rule out the false specification, serial correlation, heteroskedasticity, normalcy issues, and functional form. The cumulative sum of recursive residual (CUSUM) and cumulative sum of squares of recursive residual (CUSUMsq) tests were also applied to check the stability of the model (Brown et al. 1975).

After this, we evaluate the robustness of the long-run coefficients of the ARDL Bound approach of the model applying FMOLS (Phillips and Hansen 1990) and DOLS (Saikkonen 1991; Stock and Watson 1993) econometric methodologies.

According to Pedroni (2001a, b), the fully modified least square (FMOLS) model can be represented as follows:

$Y_{i, t}=\alpha_{i}+\beta_{i} X_{i, t}+\varepsilon_{i, t} \forall_{t}=1, \ldots, T, i=1, \ldots N$

The FMOLS technique ameliorates the serial correlation and endogeneity through a semi-parametric correction. This process erases long-term correlation among the cointegration equation and the stochastic regressor (Phillips 1995). It admits the standard Wald test that applies asymptomatic chi-square statistical inference (Hansen 1992a, 1992b).

The dynamic ordinary least squares (DOLS) econometric methodology considers orthogonality in the equation term:

$Y_{t}=\alpha_{i}+\beta X \prime_{t}+D{ }_{1 t} D^{\prime} \gamma_{1} \sum_{j=-q}^{r} \Delta X \prime_{t+j} \rho+v_{1, t}$

The DOLS technique uses intercept-trend specification without additional deterministic components and one lag and lead of the differenced cointegrating regressor to erase the long-run correlation. 
Table 3 Stationarity test result

\begin{tabular}{|c|c|c|c|c|c|c|c|}
\hline \multicolumn{4}{|c|}{ Unit root test $(\mathrm{PP})$} & \multicolumn{4}{|c|}{ Unit root test (ADF) } \\
\hline & With constant & With constant and trend & $\begin{array}{l}\text { Without } \\
\text { constant and } \\
\text { trend }\end{array}$ & & With constant & With constant and trend & $\begin{array}{l}\text { Without } \\
\text { constant and } \\
\text { trend }\end{array}$ \\
\hline \multicolumn{8}{|l|}{ At level } \\
\hline LEFP & & & & LEFP & & & \\
\hline$t$-Statistic & -0.2260 & -1.8510 & $-2.0060 * *$ & $t$-Statistic & -0.4257 & -2.0006 & $-2.0098 * *$ \\
\hline Prob. & $(0.9265)$ & $(0.6603)$ & $(0.0442)$ & Prob. & 0.8947 & 0.5828 & 0.0438 \\
\hline LGDPP & & & & LGDPP & & & \\
\hline$t$-Statistic & -0.9231 & -1.3884 & 1.5682 & $t$-Statistic & -0.5277 & -1.3152 & 1.1000 \\
\hline Prob. & $(0.7702)$ & $(0.8488)$ & $(0.9692)$ & Prob. & $(0.8745)$ & $(0.8689)$ & $(0.9265)$ \\
\hline LELE & & & & LELE & & & \\
\hline$t$-Statistic & -1.6443 & -3.0591 & 4.4674 & $t$-Statistic & -1.7840 & -3.0775 & 5.5315 \\
\hline Prob. & $(0.4510)$ & $(0.1302)$ & $(1.0000)$ & Prob. & $(0.3826)$ & $(0.1257)$ & $(1.0000)$ \\
\hline LFDI & & & & LFDI & & & \\
\hline$t$-Statistic & $-4.1799 * * *$ & $-4.8873 * * *$ & -0.9172 & $t$-Statistic & $-4.1951 * * *$ & $-4.9012 * * *$ & -1.3181 \\
\hline Prob. & $(0.0022)$ & $(0.0017)$ & $(0.3129)$ & Prob. & $(0.0021)$ & $(0.0016)$ & $(0.1702)$ \\
\hline \multicolumn{8}{|c|}{ First difference } \\
\hline dLEFP & & & & dLEFP & & & \\
\hline$t$-Statistic & $-7.9087 * * *$ & $-7.7905 * * *$ & $-6.3884 * * *$ & $t$-Statistic & $-7.9054 * * *$ & $-5.0968 * * *$ & $-6.2999 * * *$ \\
\hline $\begin{array}{l}\text { Prob. } \\
\text { dLGDPP }\end{array}$ & $(0.0000)$ & $(0.0000)$ & $(0.0000)$ & $\begin{array}{l}\text { Prob. } \\
\text { dLGDPP }\end{array}$ & $(0.0000)$ & $(0.0010)$ & $(0.0000)$ \\
\hline$t$-Statistic & $-3.6819 * * *$ & $-3.6239 * *$ & $-3.4788 * * *$ & $t$-Statistic & $-3.7123 * * *$ & $-3.7211^{* *}$ & $-3.5409 * * *$ \\
\hline $\begin{array}{l}\text { Prob. } \\
\text { dLELE }\end{array}$ & $(0.0084)$ & $(0.0410)$ & $(0.0010)$ & $\begin{array}{l}\text { Prob. } \\
\text { dLELE }\end{array}$ & $(0.0078)$ & $(0.0329)$ & $(0.0008)$ \\
\hline$t$-Statistic & $-5.9293 * * *$ & $-5.9396 * * *$ & $-3.8541 * * *$ & $t$-Statistic & $-5.9082 * * *$ & $-5.9073 * * *$ & $-3.7931^{* *}$ \\
\hline $\begin{array}{l}\text { Prob. } \\
\text { dLFDI }\end{array}$ & $(0.0000)$ & $(0.0001)$ & $(0.0003)$ & $\begin{array}{l}\text { Prob. } \\
\text { dLFDI }\end{array}$ & $(0.0000)$ & $(0.0001)$ & $(0.0004)$ \\
\hline$t$-Statistic & $-15.4282 * * *$ & $-17.3622 * * *$ & $-15.4971 * * *$ & $t$-Statistic & $-9.0799 * * *$ & $-8.9741 * * *$ & $-9.2043 * * *$ \\
\hline Prob. & $(0.0000)$ & $(0.0000)$ & $(0.0000)$ & Prob. & $(0.0000)$ & $(0.0000)$ & $(0.0000)$ \\
\hline
\end{tabular}

$* p<10 \%$;* $p<5 \%$;*** $p<1 \%$; $*$ MacKinnon (1996) one-sided $p$-values

\section{Causality test}

Most of the literature uses the Dumitrescu and Hurlin (2012) Granger causality test (Granger 1969), though it gives ambiguous results. Moreover, due to a specification issue, the Granger causality test produces erroneous and confusing findings. To address this problem, Toda and Yamamoto (1995) proposed a new causality approach. Their process determines reliable and effective analytical results in the absence of cointegration in the VAR method. Toda and Yamamoto (1995) test employs an alternative methodology to determine whether variables were neutral, bidirectional, or unidirectional. Toda and Yamamoto (1995) approach is more efficient in not requiring additional information about the properties of the variables. Our study applies the test utilized to explore the causality relationship between selected variables and used the $\operatorname{VAR}(p+d$ max $)$.

$$
\left[\begin{array}{c}
L E F P_{t-1} \\
L G D P P_{t-1} \\
L E L E_{t-1} \\
L F D I_{t-1}
\end{array}\right]=\forall_{0}+\forall_{1}\left[\begin{array}{c}
L E F P_{t-1} \\
L G D P P_{t-1} \\
L E L E_{t-1} \\
L E D I_{t-1}
\end{array}\right]+\ldots \forall_{k}\left[\begin{array}{c}
L E F P_{t-K} \\
L G D P P_{t-K} \\
L E L E_{t-K} \\
L E D I_{t-K}
\end{array}\right]+\forall_{k+1}\left[\begin{array}{c}
L E F P_{t-K-1} \\
L G D P P_{t-K-1} \\
L E L E_{t-K-1} \\
L F D I_{t-K-1}
\end{array}\right]+\forall_{k+d}\left[\begin{array}{c}
L E F P_{t-K-d} \\
L G D P P_{t-K-d} \\
L E L E_{t-K-d} \\
L F D I_{t-K-d}
\end{array}\right]
$$


Table 4 Johansen cointegration test

\begin{tabular}{lllll}
\hline \multicolumn{4}{l}{ Series: LEF LGDP LFDI LELE } \\
\hline Hypothesized & & Trace & 0.05 & \\
\hline No. of CE(s) & Eigenvalue & Statistic & Critical value & Prob.** \\
None* & $0.5821^{* * *}$ & 66.9835 & 54.0790 & $(0.0023)$ \\
At most 1 & $0.4077^{* *}$ & 33.8253 & 35.1927 & $(0.0697)$ \\
At most 2 & 0.2616 & 13.9200 & 20.2618 & $(0.2949)$ \\
At most 3 & 0.0610 & 2.39431 & 9.1645 & $(0.6986)$ \\
\hline
\end{tabular}

**MacKinnon-Haug-Michelis (1999) $p$-values: $* p<10 \%$; $* * p<5 \%$; $* * * p<1 \%$

\section{Empirical results}

Table 2 displays basic descriptive statistics and correlation matrix between LEFP, LGDPP, LELE, and LFDI. The columns show the variables' mean, median, maximum, minimum, standard deviation, Skewness, Kurtosis, and Jarque-Bera normality's test check with probability values. LGDPP and LFDI have the highest mean and median. All the variables are platykurtic since their Kurtosis value is less than 3, except LFDI. Evidence of normality exists, which is desirable. This can be deduced from their various probability values, greater than 5\%, except LFDI. Also, statistics shown from the correlation analysis and JarqueBera test indicate a positive correlation and normal distribution between LEFP, LGDPP, and electricity consumption.
Table 3 shows that the variables examined using the ADF and PP unit tests are stationary after the initial discrepancy during the first level, except LEFP and LFDI, which are stationary at level. So, we can conclude that variables are mixed, either $I(0)$ or $I(1)$ and, nonetheless, not $I(2)$. Hence, the ARDL method is preferred in such cases.

After confirming the stochastic properties of selected variables, the empirical methodology also considers analyzing the long-run connection among selected variables through the Fisher-Johansen cointegration test (1991) that integrates the individual tests and attaches them from individual crosssections (Table 4).

In a second step, the Bayer-Hanck test findings, depicted in Table 5, indicate that EG-J and EG-J-Bo-BDM's $F$-statistic values are 18.333 and 36.651 and are greater than $5 \%$ of critical value, i.e., 10.637 and 20.486, respectively. Hence, the alternative hypothesis of cointegration was accepted. Therefore, Johansen and Bayer-Hanck cointegration tests confirm a long-run cointegration between the selected variables in Algeria for the period 1975-2014.

Once the stationarity properties of the selected variables are confirmed, we advance to estimate the ARDL framework. Raza et al. (2013) stated that using more lags or using leases lags might result in the model's most strong evidence being lost, as well as a one-sided or biased estimation. As a result, having witnessed the state of perfect delays, the current research focused on the Akaike information criterion
Table 5 Bayer-Hanck test for cointegration

\begin{tabular}{|c|c|c|c|c|}
\hline \multirow[t]{2}{*}{ Test outcomes } & \multicolumn{4}{|l|}{ Underlying Tests } \\
\hline & Engle-Granger & Johansen & Banerjee & Boswijk \\
\hline Test statistics & -5.0366 & 27.7104 & -4.3822 & 21.3337 \\
\hline$p$-values & $(0.0022)^{* * *}$ & $(0.0475)^{* *}$ & $(0.0087)^{* * *}$ & $(0.0121)^{* * *}$ \\
\hline \multicolumn{5}{|c|}{ Bayer-Hanck Test } \\
\hline & Fisher Type Test statistics & & $5 \%$ critical value & \\
\hline EG-J & 18.333 & & 10.637 & \\
\hline EG-J-Bo-BDM & 36.651 & & 20.486 & \\
\hline
\end{tabular}

$* p<10 \% ; * *<<5 \% * * * p<1 \%$

Table 6 Lag length selection criterion

\begin{tabular}{llllllll}
\hline Lag & LogL & LR & FPE & AIC & SC & HQ & Specification \\
\hline 0 & 61.84896 & NA* & $0.002639^{*}$ & $-3.102720^{*}$ & $-2.838800^{*}$ & $-3.010605^{*}$ & ARDL $(1,0,0,0,0,0,0)$ \\
1 & 62.38123 & 0.857546 & 0.002713 & -3.076735 & -2.768829 & -2.969268 & \\
2 & 62.83403 & 0.704347 & 0.002804 & -3.046335 & -2.694442 & -2.923515 & \\
3 & 62.90787 & 0.110756 & 0.002962 & -2.994881 & -2.599002 & -2.856709 & -2.786841 \\
4 & 62.92660 & 0.027059 & 0.003141 & -2.940367 & -2.500500 & -15 & \\
\hline
\end{tabular}

LR, FPE, AIC, BIC, HQ represent sequentially modified LR test statistic, final prediction error, Akaike information criterion, Schwarz information criterion, and Hannan-Quinn information criterion, respectively

*Optimal lag length 
(AIC) to select the appropriate lag length for cointegration, being confirmed that the AIC is preferred in lag length selection due to its higher characteristics (Udemba and Yalçıntaş 2021; Zhang et al. 2021). Thus, the AIC lag length criterion statistic shows that the ARDL $(1,0,0,0,0,0,0)$ is the best lag order, and outcomes are stated in Table 6 . In addition, the inverse roots of AR characteristics of the polynomial graph in Figure 1 show that the model is dynamically stable because the two blue dots are inside the unit circle.

Table 7 highlights the ARDL bound test estimates. The $F$-statistic value (4.83) is greater than the upper-bound critical value at $1 \%$, implying the existence of cointegration. Thus, the Johansen and Bayer-Hanck cointegration tests were employed to verify the result of the ARDL bound test and check the robustness of an existing long-run relationship among the study variables.

The overall findings of the ARDL model are illustrated in Table 8.

The values of $R^{2}$ and adjusted- $R^{2}$ show that $98.13 \%$ and $97.78 \%$ variation in the response of ecological footprint can be explained by economic growth, electricity consumption, foreign direct investment, and the interaction between LEL and LFDI, as well as the rest of the percentage that can be attributed to the residue. For the short run, results show that the speed of adjustment is considered to facilitate the long-run relationship between coefficients with significant negative ECM. ECT value $(-0.88)$ proves the cointegration, and this signifies that the model can witness a balance at $88 \%$ speed of adjustment toward the long-run equilibrium. The econometric results reported in Table 8 confirm a nonlinear connection between real GDPP and the ecological footprint in the long run. So, these results demonstrate the EKC empirical evidence in Algeria is

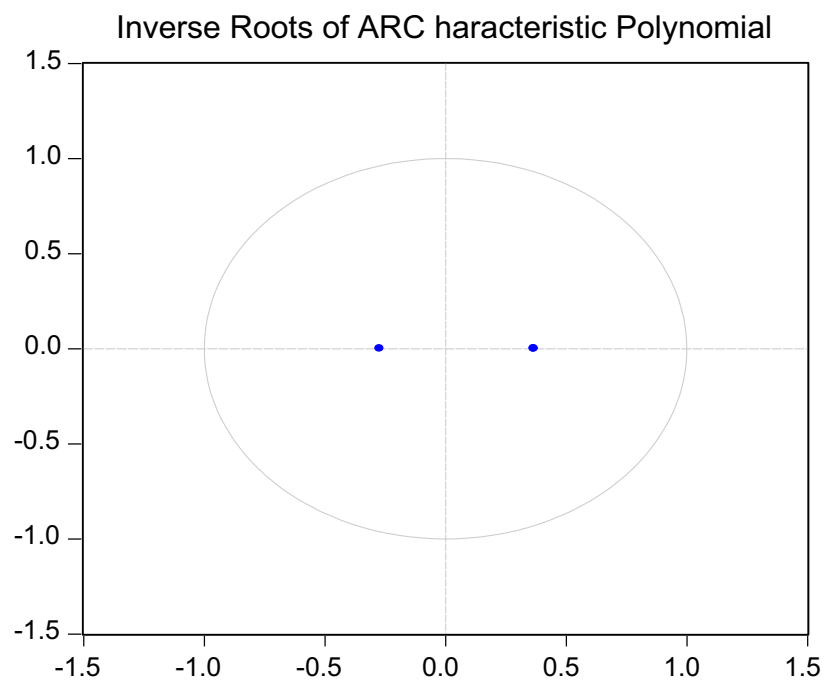

Figure 1 Autoregressive root graph
Table 7 ARDL bound test result

\begin{tabular}{lllll}
\hline & Significance & LB & UB & Cointegration \\
\hline$F$-statistic $=$ & $10 \%$ & 1.75 & 2.87 & Yes \\
$4.838482^{* * *}$ & & & & \\
& $5 \%$ & 2.04 & 3.24 & \\
& $1 \%$ & 2.66 & 4.05 & \\
\hline
\end{tabular}

$* * * p<1 \%, \mathrm{LB}$ and UB indicate the lower-bound and the upperbound, respectively

consistent (Génesis-Carolina et al. 2021). We can observe how, in the first stage of development, the EFP rises $\left(\omega_{2}>\right.$ 0 ) along with ascending per capita income (GDPP). After that, EFP decreases $\left(\omega_{3}<0\right)$. A final stage $\left(\omega_{4}>0\right)$ confirms the $\mathrm{N}$-shaped connection between economic growth and the ecological footprint in Algeria between 1975 and 2014. This understanding is in line with previous empirical literature (Al-Mulali 2011; Farhani et al. 2014; Sahli and Ben Reje 2015; Abdallh and Abugamos 2017). In other words, the $\mathrm{N}$-shaped validation implies that in the first step of economic growth, environmental quality increases till a certain turning point, where it starts to come down. In the last stage, typified by high development and low growth rate, the pollution level increases again due to technological obsolescence and inappropriate energy regulations (Álvarez-Herranz et al. 2017). In the last stage, the scale effect starts to prevail again over

Table 8 Long-run and short-run coefficient results

\begin{tabular}{lllll}
\hline Variable & Coefficient & Std. error & $t$-statistic & Prob. \\
\hline Short-run coefficients & & & & \\
D(LGDPP) & 10.7510 & 6.9394 & 1.5492 & $(0.1312)$ \\
D(LGDPP^2) & $-2.9695 *$ & 1.6942 & -1.7527 & $(0.0892)$ \\
D(LGDPP^3) & $0.1919 *$ & 0.1032 & 1.8596 & $(0.0722)$ \\
D(LELE) & $0.8621 * * *$ & 0.2099 & 4.1061 & $(0.0003)$ \\
D(LFDI) & $0.1423 * *$ & 0.0578 & 2.4594 & $(0.0195)$ \\
D(LELE*LFDI) & $-0.0229 * *$ & 0.0095 & -2.4131 & $(0.0217)$ \\
ECT $(-1)$ & $-0.8844 * * *$ & 0.1448 & -6.1036 & $(0.0000)$ \\
ECT $=$ LEFP $-(12.1562 *$ LGDPP $-3.3577 *$ LGDPP2 & \\
$\quad+0.2171 *$ LGDPP3 $+0.9748 *$ LELE $+0.1610 *$ LFDI - & \\
$0.0260 *$ LELE*LFDI $)$ & & & \\
Long-run coefficients & & & & \\
LGDPP & $12.1562 *$ & 7.2408 & 1.6788 & $(0.1029)$ \\
LGDPP^2 & $-3.3576 *$ & 1.7424 & -1.9269 & $(0.0629)$ \\
LGDPP^3 & $0.2170 * *$ & 0.1053 & 2.0603 & $(0.0476)$ \\
LELE & $0.9747 * * *$ & 0.2017 & 4.8307 & $(0.0000)$ \\
LFDI & $0.1609 * *$ & 0.0651 & 2.4693 & $(0.0191)$ \\
LELE*LFDI & $-0.0259 * *$ & 0.0106 & -2.4286 & $(0.0210)$ \\
R-squared & 0.981275 & & & \\
Adjusted R-squared & 0.977764 & & & \\
\hline$* p<10 \% ; * *<5 \% ; * * p<1 \%$ & & &
\end{tabular}


Table 9 Diagnostic tests for ARDL model

\begin{tabular}{llc}
\hline Test & $F$-statistics & $p$-value \\
\hline Breush-Pagan-Godfrey test & 0.158883 & $(0.9758)$ \\
Breush-Godfrey serial correlation & 0.228025 & $(0.7974)$ \\
$\quad$ LM test & & \\
JarqueBera test & 2.225337 & $(0.3287)$ \\
Ramsey Rest test & 0.010911 & $(0.9175)$ \\
\hline
\end{tabular}

composition and technical effect where environmental protection measures would correct technological obsolescence (Balsalobre-Lorente and Álvarez-herranz 2016; BalsalobreLorente et al. 2018; Shahbaz et al. 2018). Otherwise, the electricity consumption presents a direct connection with the EFP $\left(\omega_{5}>0\right)$, suggesting that fossil sources dominate the energy mix in Algeria. Otherwise, our empirical results also reflect that FDI directly affects EFP, validating the pollution haven hypothesis in Algeria (Udemba and Yalçıntaş 2021). The empirical evidence confirms that FDI increases the EFP in Algeria $\left(\omega_{6}>0\right)$. Finally, the interaction between FDI and electricity consumption presents a negative connection with the EFP $\left(\omega_{7}<0\right)$. The nexus between FDI-electricity consumption and the EFP confirms the necessity to promote economic sectors supported by foreign investment. This fresh evidence contains significant policy implications for this country and the context of the FDI gold decade. In this sense, the interaction effect confirms the positive effects of FDI over the energy mix in Algeria due to the attraction of a clean industry with more efficient energy usage. For this reason, the Algeria administration needs to attract clean and high-tech industries for reducing environmental pressure. Additionally, this result indicates that in the absence of stringent environmental protocols and forfeits for polluters, the economic development for Algeria is related to ascending pollution levels (He 2006; Neequaye and Oladi 2015).
Subsequently, the administration should promote to attract investment in clean industries and services, which will increase environmental protection (Cole and Elliott 2003; Managi et al. 2012). Otherwise, Algeria policymakers must promote the purchase of clean inputs to restructure international trade, improve the administrative structure necessary for efficient capital liberalization, and attract additional FDI inflows. The promotion of renewable sources and efficient energy usage would contribute to reducing the ecological footprint. Lastly, governments in this region should act against corruption and perform correct property rights in the country (Abdouli et al. 2018).

Table 9 shows the heteroskedasticity, serial correlation, normality, and functional form testing, used as diagnostic tests in the studies. Findings reveal the absence of heteroskedasticity and serial correlation, as pointed out by BreushPagan-Godfrey's $F$-statistic of LM tests, respectively. Thus, results are void of the error correction definition (Farhani et al. 2014; Pan and Dossou 2020). Besides, the $p$-value of the Jarque-Bera test, which is greater than $10 \%$, recommends that errors are normally distributed. Ramsey RESET test is also employed to check for the suitable functional form. So, the model is well specified, as the probability value is 0.9175 .

After performing the diagnostic tests (Table 9), the shortand long-run ARDL estimates are examined by performing the CUSUM and CUSUMsq experiments (Figure 2), revealing a constancy of the fitted model.

The empirical evidence is reinforced by applying the FMOLS and cointegration techniques to bolster the ARDL long-run econometric results (Table 10).

The outcomes of the FMOLS method endorse the existence of $\mathrm{N}$-shaped EKC between the ecological footprint and economic growth as the signs of the coefficients of LGDP, LGDPP $^{2}$, and LGDPP $^{3}$ confirm a nonlinear N-shaped behavior, statistically significant at $1 \%$. The DOLS model result is
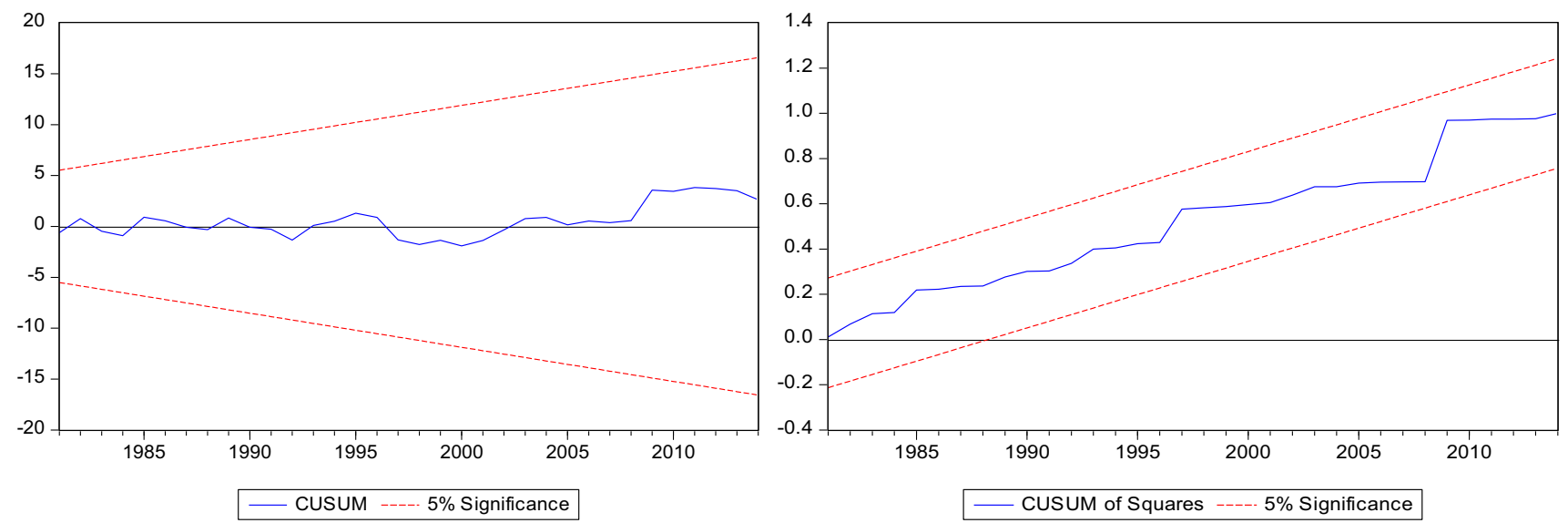

Figure 2 Plot of the CUSUM and the CUSUM of squares 
Table 10 FMOLS \& DOLS main econometric results

\begin{tabular}{|c|c|c|c|}
\hline \multicolumn{4}{|c|}{$\begin{array}{l}\text { Dependent Variable: LEFP } \\
\text { Sample: } 19752014\end{array}$} \\
\hline Variable & OLS & FMOLS & DOLS \\
\hline \multirow[t]{3}{*}{ LGDPP } & $17.07751 * * *$ & $18.32820 * * *$ & $18.70728 * * *$ \\
\hline & {$[3.223754$} & [3.715757] & [3.208241] \\
\hline & $(0.0028)$ & $(0.0007)$ & $(0.0069)$ \\
\hline \multirow[t]{3}{*}{$\mathrm{LGDPP}^{\wedge} 2$} & -4.520264 & $-4.811152 * * *$ & $-5.350193 * * *$ \\
\hline & {$[-3.519550]$} & {$[-4.048318]$} & {$[-3.865229]$} \\
\hline & $(0.0013)$ & $(0.0003)$ & $(0.0020)$ \\
\hline \multirow[t]{3}{*}{ LGDPP^3 } & $0.286665 * * *$ & $0.304032 * * *$ & $0.349791 * * *$ \\
\hline & [3.677213] & {$[4.227451]$} & [4.188691] \\
\hline & $(0.0008)$ & $(0.0002)$ & $(0.0011)$ \\
\hline \multirow[t]{3}{*}{ LELE } & $0.885024 * * *$ & $0.838659 * * *$ & $2.125080 * * *$ \\
\hline & {$[5.311521$} & [6.073901] & [5.714565] \\
\hline & $(0.0000)$ & $(0.0000)$ & $(0.0001)$ \\
\hline \multirow[t]{3}{*}{ LFDI } & $0.134955^{* * *}$ & $0.121419 * * *$ & $0.525260 * * *$ \\
\hline & [2.468859] & [2.741419] & [4.676859] \\
\hline & $(0.0187)$ & $(0.0098)$ & $(0.0004)$ \\
\hline \multirow[t]{3}{*}{ LFDI*LELE } & $-0.021735 * * *$ & $-0.019447 * * *$ & $-0.085393 * * *$ \\
\hline & {$[-2.421794]$} & {$[-2.672263]$} & {$[-4.604120]$} \\
\hline & $(0.0209)$ & $(0.0116)$ & $(0.0005)$ \\
\hline R-squared & 0.981775 & 0.980181 & 0.992494 \\
\hline Adjusted R-squared & 0.979094 & 0.977178 & 0.979215 \\
\hline S.E. of regression & 0.047244 & 0.047853 & 0.041634 \\
\hline Sum squared resid. & 0.075888 & 0.001368 & 0.000488 \\
\hline Log-likelihood & 68.59005 & & \\
\hline Durbin-Watson stat & 2.108168 & & \\
\hline Mean dependent var. & -0.235896 & -0.220894 & -0.220347 \\
\hline S.D. dependent var. & 0.326749 & 0.316757 & 0.288785 \\
\hline Akaike info criterion & -3.129503 & 0.075566 & 0.022534 \\
\hline Schwarz criterion & -2.876171 & & \\
\hline Hannan-Quinn criteria & -3.037906 & & \\
\hline
\end{tabular}

Values in brackets indicate $t$-statistics

$* p<10 \% ; * * p<5 \% * * * p<1 \%$ a replica of the FMOLS model in terms of signs and significance degree. The variable of interaction between electricity consumption and FDI is appropriately signed with a negative coefficient across both econometric methods. Results are reliable with the existence of a long-run relationship among variables. In addition, the high values of adjustedR-squared disclose that the fit of variables in FMOLS and DOLS models is strong ( $97.72 \%$ and $97.92 \%$, respectively). So, the findings from FMOLS and DOLS are also conclusive and comply with the ARDL long-run estimates. The
Table 11 Toda-Yamamoto noncausality analysis

\begin{tabular}{lllll}
\hline & LEFP & LGDPP & LELE & LFDI \\
\hline LEFP & - & $0.902817(0.6367)$ & $3.330501(0.1891)$ & $0.493407(0.7814)$ \\
LGDPP & $7.173115^{* *}(0.0277)$ & - & $0.783030(0.6760)$ & $5.676408^{*}(0.0585)$ \\
LELE & $5.007548^{*}(0.0818)$ & $0.543373(0.7621)$ & - & $\begin{array}{l}2.694550 \\
(0.2599)\end{array}$ \\
LFDI & $2.787769(0.2481)$ & $0.373171(0.8298)$ & $1.870972(0.3924)$ & - \\
\hline
\end{tabular}

$* p<10 \% ; * * p<5 \% ; * * * p<1 \%$ 


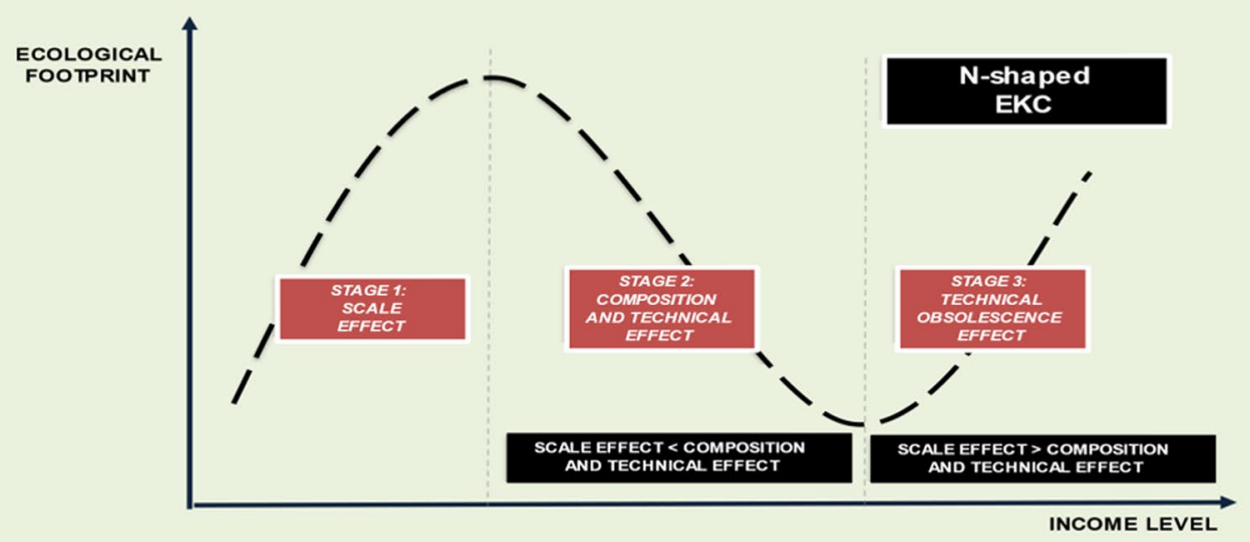

Figure $3 \mathrm{~N}$-shaped EKC

consequences of our empirical results confirm that an effective pollution control policy will reduce through cleaner energy use (Bilgili 2012; Lin and Moubarak 2014; Adewuyi and Awodumi 2017).

Finally, we apply the Toda-Yamamoto non-causality test (Toda and Yamamoto 1995) that explores the causal connection among variables (Table 11). These findings show a unidirectional causality between economic growth and ecological footprint, just as had been shown in the research on the United Arab Emirates by Shahbaz et al. (2020) or by Danish et al. (2020) in Japan, Canada, Italy, USA, and Germany, and Nathaniel et al. (2020) in the Middle East and North African region. This evidence helped to clarify that the increase in Algeria's ecological footprint results from increased economic activities.

Causality analysis reveals that electricity consumption is a causal factor for ecological footprint. More so, the Algerian government should adopt electric power sources in their domestic or commercial activities. This finding complements those of de Mehmood (2021), who also discovered the same direction of causality for SAARC countries. Also, this study confirms one-run relationship flows from economic growth per capita toward foreign direct investment. This outcome is corroborated by previous studies which support the finding that FDI has a crucial role in stimulating the long-run economic growth (Kivyiro and Arminen 2014; Tan and Tang 2016; Sunde 2017; Goh et al. 2017; Sarker and Khan 2020). In this regard, Algerian policymakers should pay more attention to the policies for attracting inward FDI.

\section{Discussion and policy implications}

The empirical evidence (Tables 8 and 10) confirms an N-shaped EKC connection (Sahli and Ben Reje 2015; Abdallh and Abugamos 2017) between economic growth and the ecological footprint in Algeria between 1975 and 2014.

Figure 3 illustrates how the EFP rises along with rising economic growth in the first stage of development. This pattern reveals a transition to a developed stage, where FDI and electricity consumption directly affects the ecological footprint. The econometric results confirm the interaction between FDI and electricity consumption, and this result is essential to avoid technical obsolescence and reduce environmental pressure. After that, during phase 2, EFP decreases until a certain turning point, where economic growth contributes to increasing EFP. The final stage confirms the $\mathrm{N}$-shaped connection between economic growth and the ecological footprint. During phase 3 (see Figure 3), the prevalence of the scale effect will generate ascending degradation (Balsalobre-Lorente et al. 2018; Shahbaz et al. 2018). This result considers that ascending income will contribute to growth rate, appearing a new increase of the ecological footprint due to the absence of appropriate innovations and the promotion of renewable energy sources (Álvarez-Herranz et al. 2017).

Otherwise, the empirical evidence also supports the pollution haven hypothesis in Algeria, revealing a direct connection between FDI and the ecological footprint (Udemba and Yalçıntaş 2021). This direct linkage implies the 
necessity of implementing a high-tech industry in Algeria to reduce the pernicious effects of FDI on the environment. For this proposal, the Administration should promote foreign initiatives and strategies in energy innovation processes to generate a transition to clean and high-tech economies.

The electricity consumption directly correlates with the EFP, suggesting that fossil sources dominate the energy mix in Algeria.

The key finding of this study is the existence of an interaction (Cohen et al. 2013) between FDI and electricity consumption, which negatively connects with the EFP. This evidence is fundamental for understanding how the attraction of foreign industry can generate more efficient energy processes in the host country. In other words, the nexus between FDI-electricity consumption and the EFP confirms the necessity of advance in the promotion of more efficient energy processes supported by foreign investment. Therefore, the investment in clean industries will enhance stringent environmental regulation, diminishing ecological pressure (Cole and Elliott 2003; Managi et al. 2012). Being imperative to act against corrupt practices, incrementing rights policies for public goods, promoting more efficient and cleaner energy usage (Abdouli et al. 2018; Sinha et al. 2017; Kasperowicz 2015; Bilgili 2012; Lin and Moubarak 2014; Adewuyi and Awodumi 2017); where advanced FDI would provide investments in $\mathrm{R} \& \mathrm{D}$, technologies, and advances in the energy industry (Ndlovu and Inglesi-Lotz 2020; Wu et al. 2020).

Hence, Algeria should promote the attraction of cleaner and high-tech foreign businesses to control environmental pressure and reach sustainable economic growth, related to a new FDI golden decade (UNCTAD 2020). By contrast, in the absence of strict protocols, FDI would be part of pollutant manufacturing firms (He 2006; Neequaye and Oladi 2015).

Based on the stated results, some significant policy implications should be implemented. For instance, both government and private industry should coordinate active measures. In this sense, the Administration promotes clean energy sources increasing renewable sources, while the private sector should implement measures in strategic sectors like tourism or the high-tech industry, attracting foreign business to Algeria.

\section{Final conclusions}

This study examines the effect of electric consumption, FDI, the interaction between them, and economic expansion on the ecological footprint in Algeria from 1975 to 2014. In particular, we find evidence of an $\mathrm{N}$-shaped environmental Kuznets curve (N-shaped EKC). This study enhances the EKC literature by clarifying the relationship hypothesis between economic growth per capita and ecological footprint in a globalized economic system. The main objective of this study has been to present a battery of recommendations aimed to achieve a transition to sustainable growth based on technology and more efficient energy processes. For this purpose, we consider that promoting advanced FDI and clean energy usage are fundamental driving forces to advance to a developed stage of economic growth.

The ARDL econometric technique is employed to confirm the long-term presence of the N-shaped EKC hypothesis after checking the stationary properties of selected variables through the traditional ADF and PP unit root tests. We have also applied Johansen-Fisher and Bayer Hanck cointegration methodologies, demonstrating long-run connections among selected variables. In a second step, we have applied the FMOLS and DOLS econometric to confirm the empirical procedure's robustness. The causality direction is also checked in the final empirical strategy by applying the Toda-Yamamoto non-causality test.

According to the N-shaped relationship between economic growth and the ecological footprint, both FDI and electric consumption increase the ecological footprint in Algeria; as a result of the need for agreement, uniformity of analyses, and results of previous studies on the impact of economic growth on the quality of the environment and its contribution to the ecological footprint in the case of Algeria. So, we clarify the relationship between these study variables and ask the following questions: To what extent can Algeria contribute to balancing the usage of its electric energies and the sustainability of its environment to preserve for future generations? Is it possible that the foreign-direct investment contributes to increasing the ecological footprint in the case of Algeria, and what is the effect of economic growth per capita on the ecological footprint?

Electricity consumption increases the ecological footprint. Similarly, foreign direct investment positively impacts ecological footprint, while the interaction term between FDI and electricity consumption contributed negatively to the EFP. The current study fills the research gap by investigating the $\mathrm{N}$-shaped EKC hypothesis in Algeria by using several variables to estimate and elucidate the connections between economic growth, electricity consumption, foreign direct investment, the interaction between electricity consumption and FDI, and the ecological footprint.

This evidence implies that it is necessary to adopt measures related to the transition from a developing industry to a hightech and clean industry in Algeria, where adopting environmentally friendly measures will generate sustainable growth.

Furthermore, the Algerian government must improve the economy's structure to limit the overuse of fossil resources, protect the environment for future generations, and develop systems for assessing and monitoring the impacts of FDI on the Algerian economy. 
The findings indicated that the economic growth sector presents an $\mathrm{N}$-shaped linkage with the ecological footprint in Algeria, validating the EKC hypothesis. So, initially, environmental degradation increases in the early stages of economic growth; however, at the later stages of the growth process, the ecological footprint starts decreasing, till a certain point, where without the proper measures, the ecological footprint would present ascending behavior again. On the other hand, without the share of fossil sources in their energy mix, it implies ascending pollution in Algeria, being necessary to promote renewable sources in the region. Finally, the FDI presents a positive connection with the ecological footprint in Algeria, validating the $\mathrm{PHH}$.

Algeria should transfer energy from resource-rich industries to industrial sectors to boost economic growth, promoting economic development. Economic and environmental policymakers should advance in creating environmental rules and standards to minimize the negative impacts of dirty foreign industries protecting Algeria from sources of pollution that may enter the country. Concerning other environmental quality factors, energy consumption and clean foreign investment should be considered by policymakers. In this respect, fossil energy sources still have a high share in the energy mix of Algeria.

On the other hand, long-run growth indications require low-carbon strategies to develop an economic model based on environmental sustainability. Algeria should proceed in implementing stringent regulations, promoting renewable sources and attracting high-tech foreign investment. We have outlined that the connection between FDI and energy consumption contributes to controlling the harmful effects of fossil sources in the energy mix. Even the FDI presents a direct link with the ecological footprint in Algeria. Foreign investments can contribute to implementing clean and more efficient energy sources. So, the policymakers attract innovation measures to reduce the scale effect, advancing implementation.

Hence, for Algeria, deregulation in the energy industry is necessary, which will allow diversification of energy sources and promote cleaner energy sources. So, the private sector should invest in renewable sources. This country also requires an increase of high-tech products affordable for public and private economic activities. At the same time, there should be the implementation of different tax policies for carbon-intensive industries aimed to avoid dirty business. In other words, regulation of carbon emission through these energy policies will contribute to decarburizing Algeria.

Consequently, it would be helpful to increase efforts to improve environmental policies and institutions rather than restricting foreign activities that reduce environmental quality.

Finally, this study was prepared without a few limitations. Firstly, the scope of this research is limited to Algeria, which includes data from 1970 to 2014, where future studies should extend the period for prospective analyses. Then, future research might give an immersive word for a specific aspect of globalization (economics, social, and culture), focused on the crisis COVID-19 and the analysis of the natural resources crisis in the region.

Availability of data and material Under justified request.

Authors contribution MC: empirical methodology, introduction, literature review and discussion. DBL: theoretical approach, empirical discussion, literature review, conclusions and policy implications

\section{Declarations}

Ethics approval Not applicable

Consent to participate Not applicable

Consent for publication Not applicable

Competing interests The authors declare no competing interests.

\section{References}

Abdallh AA, Abugamos H (2017) A semi-parametric panel data analysis on the urbanization-carbon emissions nexus for the MENA countries. Renew Sust Energ Rev 78:1350-1356

Abdouli M, Kamoun O, Hamdi B (2018) The impact of economic growth, population density, and FDI infows on $\mathrm{CO} 2$ emissions in BRICTS countries: does the Kuznets curve exist? Empir Econ 54(4):1717-1742

Adebayo TS, Demet BK (2020) Ongoing debate between foreign aid and economic growth in Nigeria: a Wavelet Analysis. Social science quarterly, Southwestern social science association 101(5):2032-2051

Adebayo TS, Kirikkaleli D (2021) Impact of renewable energy consumption, globalization, and technological innovation on environmental degradation in Japan: application of wavelet tools. Environ Dev Sustain 4(2):1-26

Adewuyi AO, Awodumi O (2017) Renewable and non-renewable energy-growth-emissions linkages: review of emerging trends with policy implications. Renew Sust Energ Rev 69(C):275-291

Ahmed Z, Wang Z, Mahmood F, Hafeez M, Ali N (2019) Does globalization increase the ecological footprint? Empirical evidence from Malaysia. Environ Sci Pollut Res 26(18):18565-18582

Akrour S, Moore J, Grimes S (2021) Assessment of the ecological footprint associated with consumer goods and waste management activities of south Mediterranean cities: case of Algiers and Tipaza. Environmental and Sustainability Indicators, 100154

Al-Mulali U (2011) Oil consumption, CO2 emission and economic growth in MENA countries. Energy 36(10):6165-6171

Álvarez-Herranz A, Balsalobre Lorente D (2016) Economic growth and energy regulation in the environmental Kuznets curve. Environ Sci Pollut Res 23(16):16478-16494

Álvarez-Herranz A, BalsalobreLorente D (2015) Energy regulation in the EKC model with a dampening effect. Int J Environ Anal Chem 2(3): 1-10

Álvarez-Herranz A, Balsalobre-Lorente D, Shahbaz M, Cantos JM (2017) Energy innovation and renewable energy consumption in the correction of air pollution levels. Energy Policy 105:386-397 
Ansari, M. A., Ahmad, M. R., Siddique, S., \& Mansoor, K. (2020). An environment Kuznets curve for ecological footprint: Evidence from GCC countries. Carbon Management, 0(0), 1-14.

Ansari MA, Haider S, Masood T (2021) Do renewable energy and globalization enhance ecological footprint: an analysis of top renewable energy countries? Environ Sci Pollut Res 28(6):6719-6732

Ayobamiji AA, Kalmaz DB (2020) Reinvestigating the determinants of environmental degradation in Nigeria. Int J Econ Policy Emerg Econ 13(1):52-71

Aziz N, Sharif A, Raza A, Rong K (2020) Revisiting the role of forestry, agriculture, and renewable energy in testing environment Kuznets curve in Pakistan: evidence from Quantile ARDL approach. Environ Sci Pollut Res 27(9):10115-10128

Balsalobre-Lorente D, Álvarez-herranz A (2016) Economic growth and energy regulation in the environmental Kuznets curve. Environ Sci Pollut Res 23:16478-16494

Balsalobre-Lorente D, Shahbaz M, Roubaud D, Farhani S (2018) How economic growth, renewable electricity and natural resources contribute to $\mathrm{CO} 2$ emissions? Energy Policy 113(November 2017):356-367

Balsalobre-Lorente D, Gokmenoglu KK, Taspinar N, Cantos-Cantos JM (2019) An approach to the pollution haven and pollution halo hypotheses in MINT countries. Environ Sci Pollut Res 26(22):23010-23026

Banerjee A, Dolado JJ, Mestre R (1998) Error-correction mechanism tests for cointegration in a single equation framework. J Time Ser Anal 19:267-283

Bayer C, Hanck C (2013) Combining non-cointegration tests. 2012 (May 2008)

Bekun FV, Alola AA, Gyamfi BA, Ampomah AB (2021) The environmental aspects of conventional and clean energy policy in sub-Saharan Africa: is N-shaped hypothesis valid? Environ Sci Pollut Res:1-14

Belaid F, Youssef M (2017) Environmental degradation, renewable and non-renewable electricity consumption, and economic growth: Assessing the evidence from Algeria. Energy Policy 102:277-287

Bilgili F (2012) The impact of biomass consumption on CO2 emissions: cointegration analyses with regime shifts. Renew Sust Energ Rev 16(7):5349-5354

Boswijk HP (1994) Testing for an unstable root in conditional and structural error correction models. J Econ 63:37-60

Boufateh T, Saadaoui Z (2020) Do asymmetric financial development shocks matter for $\mathrm{CO} 2$ emissions in Africa? A Nonlinear Panel ARDL-PMG Approach. Environ Model Assess 25(6):809-830

Bouznit M, Pablo-Romero MDP (2016) CO2 emission and economic growth in Algeria. Energy Policy 96:93-104

Brown RL, Durbin J, Evans JM (1975) Techniques for testing the constancy of regression relations over time. J R Stat Soc B-37:149-192

Chowdhury MAF, Shanto PA, Ahmed A et al (2021) Does foreign direct investments impair the ecological footprint? New evidence from the panel quantile regression. Environ Sci Pollut Res 28:14372-14385

Cohen D, Cassel RS, Saint-Georges C, Mahdhaoui A, Laznik MC, Apicella F, Chetouani M (2013) Do parentese prosody and fathers' involvement in interacting facilitate social interaction in infants who later develop autism? Plos one 8(5):e61402

Cole MA, Elliott RJ (2003) Determining the trade-environment composition effect: the role of capital, labor and environmental regulations. J Environ Econ Manag 46(3):363-383

Danish, Ulucak R, Khan SUD (2020) Determinants of the ecological footprint: role of renewable energy, natural resources, and urbanization. Sustain Cities Soc 54:101996
Destek MA, Okumus I (2019) Does pollution haven hypothesis hold in newly industrialized countries? Evidence from ecological footprint. Environ Sci Pollut Res 26(23):23689-23695

Dickey DA, Fuller WA (1979) Distribution of the estimators for autoregressive time series with a unit root. J Am Stat Assoc 74:427-431

Dogan E, Inglesi-Lotz R (2020) The impact of economic structure to the environmental Kuznets curve (EKC). In: hypothesis: evidence from European countries. Environmental Science and Pollution Research, pp 1-8

Du J, Zhang Y (2018) Does One Belt One Road initiative promote Chinese overseas direct investment? China Econ Rev 47:189-205

Dumitrescu EI, Hurlin C (2012) Testing for Granger non-causality in heterogeneous panels. Econ Model 29(4):1450-1460

Ekeocha DO (2021) Urbanization, inequality, economic development and ecological footprint: searching for turning points and regional homogeneity in Africa. J Clean Prod 291:125244

Engle RF, Granger CWJ (1987) Co-integration and error correction: representation, estimation and testing. Econometrica 55:251-276

Farhani S, Chaibi A, Rault C (2014) CO2 emissions, output, energy consumption, and trade in Tunisia. Econ Model 38:426-434

Génesis-Carolina TG, Viviana TD, Wilman-Santiago OM (2021 June). Expenditure on R\&D, GDP and its impact on the Ecological footprint in South America. In 2021 16th Iberian Conference on Information Systems and Technologies (CISTI) (pp. 1-8). IEEE.

Gill AR, Viswanathan KK, Hassan S (2018) A test of environmental Kuznets curve (EKC) for carbon emission and potential of renewable energy to reduce green house gases (GHG) in Malaysia. Environ Dev Sustain 20(3):1103-1114

Goh SK, Sam CY, McNown R (2017) Re-examining foreign direct investment, exports, and economic growth in Asian economies using a bootstrap ARDL test for cointegration. J Asian Econ $51: 12-22$

Granger CWJ (1969) Investigating causal relations by econometric models and cross-spectral methods. Econometrica 37:424-438

Grossman G, Krueger A (1991) Environmental impacts of a North American Free Trade Agreement. In National Bureau of Economic Research: Vol. NEER Worki (Issue 3914).

Gyamfi BA, Adedoyin FF, Bein MA, Bekun FV (2021) Environmental implications of $\mathrm{N}$-shaped environmental Kuznets curve for E7 countries. Environ Sci Pollut Res:1-11

Gygli S, Haelg F, Potrafke N, Sturm J-E (2019) The KOF Globalisation Index-revisited The Review of International Organizations. Rev Int Organ 14(3):543-574

Hansen BE (1992a) Testing for parameter instability in linear models. J Policy Model 14(August 1991):517-533

Hansen BE (1992b) Testing for parameter instability in regressions with I(1) processes. J Bus Econ Stat 10:321-335

Hassan ST, Xia E, Huang J, Kan NH (2019) Natural resources, globalization, and economic growth: Evidence from Pakistan. Environmental Science and Pollution Research

He J (2006) Pollution haven hypothesis and environmental impacts of foreign direct investment: the case of industrial emission of sulfur dioxide (SO2) in Chinese provinces. Ecol Econ 60:228-245

Ike GN, Usman O, Sarkodie SA (2020) Fiscal policy and CO2 emissions from heterogeneous fuel sources in Thailand: evidence from multiple structural breaks cointegration test. Sci Total Environ 702:134711

IMF. (2020). Algeria restrictions hitting foreign investment: IMF Hamid Ould Ahmed, Christian Low (Accessed 07 nov 2021).

Johansen S (1991) Estimation and hypothesis testing of cointegration vectors in gaussian vector autoregressive models. Econometrica Econometric Society 59(6):1551-1580

Kasperowicz R (2015) Economic growth and CO2 emissions: the ECM analysis. J Int Stud 7(3):90-97

Kirikkaleli D, Sokri A, Candemir M, Ertugrul HM (2018) Panel cointegration: long-run relationship between internet, electricity 
consumption and economic growth. Evidence from OECD Countries. InvestigaciónEconómica 77(303):161-176

Kirikkaleli D, Adebayo TS, Khan Z, Ali S (2020) Does globalization matter for ecological footprint in Turkey? Evidence from dual adjustment approach. Environ Sci Pollut Res, 1-9.

Kirikkaleli D, Adebayo TS, Khan Z, Ali S (2021) Does globalization matter for ecological footprint in Turkey? Evidence from dual adjustment approach. Environ Sci Pollut Res 28(11):14009-14017

Kivyiro P, Arminen H (2014) Carbon dioxide emissions, energy consumption, economic growth, and foreign direct investment: causality analysis for Sub-Saharan Africa. Energy 74:595-606

Lacheheb M, Rahim ASA, Sirag A (2015) Economic growth and carbon dioxide emissions: investigating the environmental Kuznets curve hypothesis in Algeria. Int J Energy Econ Policy 5(4):1125-1132.7

Latifa L, Yang KJ, Xu RR (2014) Economic growth and CO2 emissions nexus in Algeria: a cointegration analysis of the environmental Kuznets curve. Int J Econ, Commer Res 4(4):1-14

Layachi OB (2019) Effects of energy prices on environmental pollution: testing environmental Kuznets Curve for Algeria. 670216917

Lin B, Moubarak M (2014) Renewable energy consumption - economic growth nexus for China. Renew Sust Energ Rev 40(C):111-117

Liu H, Kim H (2018) Ecological footprint, foreign direct investment, and gross domestic production: evidence of Belt \& Road Initiative Countries. Sustainability 10(10):3527

MacKinnon JG, Haug AA, Michelis L (1999) Numerical distribution functions of likelihood ratio tests for cointegration. J Appl Econ 14:563-577

Managi S, Okimoto T, Matsuda A (2012) Do socially responsible investment indexes outperform conventional indexes? Appl Financ Econ 22(18):1511-1527

Mehmood U (2021) Biomass energy consumption and its impacts on ecological footprints: analyzing the role of globalization and natural resources in the framework of EKC in SAARC countries. Environ Sci Pollut Res:1-8

Naqvi SAA, Shah SAR, Anwar S, Raza H (2021) Renewable energy, economic development, and ecological footprint nexus: fresh evidence of renewable energyenvironment Kuznets curve (RKC) from income groups. Environ Sci Pollut Res 28(2):2031-2051

Nathaniel S, Anyanwu O, Shah M (2020) Renewable energy, urbanization, and ecological footprint in the Middle East and North Africa region. Environ Sci Pollut Res 27:14601-14613

Nazir MI, Nazir MR, Hashmi SH, Ali Z (2018) Environmental Kuznets curve hypothesis for Pakistan: empirical evidence form ARDL bound testing and causality approach. Int J Green Energy 15(14-15):947-957

Ndlovu V, Inglesi-Lotz R (2020) The causal relationship between energy and economic growth through research and development (R\&D): the case of BRICS and lessons for South Africa. Energy 199:117428

Neequaye NA, Oladi R (2015) Environment, growth, and FDI revisited. Int Rev Econ Financ 39:47-56

Obobisa ES, Chen H, Boamah KB, Ayamba EC, Mensah CN, Amowine N (2021) Environmental pollution of China to foreign investors: detrimental or beneficial? Environ Sci Pollut Res 28(11):13133-13150

Ouattara B (2004) Modelling the long run determinants of private investment in Senegal. Economics, Discussion Paper Series. 0413, Economics, The University of Manchester. https://ideas.repec.org/p/ man/sespap/0413.html. Accessed 2 Nov 2021

Pan XM, Dossou TAM (2020) The relationship between tourism and sustainable economic growth in the Republic of Benin. Curr Issue Tour 23(7):785-794
Pedroni P (2001a) Purchasing power parity tests in cointegrated panels. Rev Econ Stat 83:727-731

Pedroni P (2001b) Fully modified OLS for heterogeneous cointegrated panels. In: Baltagi BH, Fomby TB, Hill RC (eds) Non Stationary Panels, Panel Cointegration, and Dynamic Panels (Advances in Econometrics), vol 15. Emerald Group Publishing Limited, United Kingdom, pp 93-130

Pesaran MH, Shin Y, Smith RJ (2001) Bounds testing approaches to the analysis of level relationships. J Appl Econ 16(3):289-326

Phillips PC (1995) Fully modified least squares and vector autoregression. Econometrica. J Econom Soc:1023-1078

Phillips PCB, Hansen B (1990) Statistical inference in instrumental variables regression with I(1) processes. Rev Econ Stud 57:99-125

Phillips PCB, Perron P (1988) Testing for a unit root in time series regression. Biometrika 75(2):335-346

Qian WJ, He CF (2010) The relationship of economic growth and environment: from the perspective of ecological footprint. Ecol Econ $10: 24-29$

Rahmane A, Benelbar MH, Traich M (2021) The nexus between sustainable energy and ecological footprint: evidence from Algeria. Sustainability: Science, Practice and Policy 17(1):323-333

Raza SA, Jawaid ST, Afshan S (2013) Munich personal repec archive is stock market sensitive to foreign capital inflows and economic growth? Evidence from Pakistan (Preliminary Draft ). 48399

Rjoub H, Odugbesan JA, Adebayo TS, Wong WK (2021) Sustainability of the moderating role of financial development in the determinants of environmental degradation: evidence from Turkey. Sustainability 13(4):1-18

Rudolph A, Figge L (2017) Determinants of ecological footprints: what is the role of globalization? Ecol Indic 81(August 2016):348-361

Sabir S, Gorus MS (2019) The impact of globalization on ecological footprint: empirical evidence from the South Asian countries. Environ Sci Pollut Res 26(32):33387-33398

Sahli I, Ben Reje J (2015) The environmental Kuznets curve and corruption in the MENA region. Procedia Soc Behav Sci 195:1648-1657

Sahnoune F, Belhamel M, Zelmat M, Kerbachi R (2013) Climate change in Algeria: vulnerability and strategy of mitigation and adaptation. Energy Procedia 36:1286-1294

Saikkonen P (1991) Asymptotically efficient estimation of cointegration regressions. Economic Theory 7:1-21

Sarker B, Khan F (2020) Nexus between foreign direct investment and economic growth in Bangladesh: an augmented autoregressive distributed lag bounds testing approach. Financial Innovation 6(10)

Sarkodie SA, Strezov V (2019) Effect of foreign direct investments, economic development and energy consumption on greenhouse gas emissions in developing countries. Sci Total Environ 646:862-871

Shahbaz M, Nasir MA, Roubaud D (2018) Environmental degradation in France: the effects of FDI, financial development, and energy innovations. Energy Econ 74:843-857

Shahbaz M, Haouas I, Sohag K, Ozturk I (2020) The financial development-environmental degradation nexus in the United Arab Emirates : the importance of growth, globalization and structural breaks

Sinha A, Shahbaz M, Balsalobre D (2017) Exploring the relationship between energy usage segregation and environmental degradation in N-11 countries. J Clean Prod 168:1217-1229

Stock JH, Watson MW (1993) A simple estimator of cointegrating vectors in higher order integrated systems. Econometrica 61:783-820

Sunde T (2017) Foreign direct investment, exports, and economic growth: ADRL and causality analysis for South Africa. Res Int Bus Financ 41:434-444

Tan BW, Tang CF (2016) Examining the causal linkages among domestic investment, FDI, trade, interest rate and economic growth in ASEAN-5 countries. Int J Econ Financ Issues 6:214-220

Toda HY, Yamamoto T (1995) Statistical inference in vector autoregressions with possibly integrated processes. J Econ 66(1-2):225-250 
Udemba EN, Yalçıntaş S (2021) Interacting force of foreign direct invest (FDI), natural resource and economic growth in determining environmental performance: a nonlinear autoregressive distributed lag (NARDL) approach. Res Policy 73:102-168

Ulucak R, Bilgili F (2018) A reinvestigation of EKC model by ecological footprint measurement for high, middle and low income countries. Journal of Cleaner Production Elsevier Ltd 188:144-157

UNCTAD (2020) World Investment Report 2020. International Production Beyond the Pandemic (Accessed 07 nov 2021)

Wang J, Dong K (2019) What drives environmental degradation? Evidence from 14 Sub-Saharan African countries. Sci Total Environ 656:165-173

WORLD BANK (2019) Doing Business 2020.October 24, 2019 (Accessed 07 nov 2021).

Wu Y, Gu F, Ji Y, Guo J, Fan Y (2020) Technological capability, ecoinnovation performance, and cooperative R\&D strategy in new energy vehicle industry: evidence from listed companies in China. J Clean Prod 261:121-157

Xu C, Yiwen Z, Cheng B, Li L, Zhang M (2020) Study on environmental Kuznets curve for noise pollution: a case of 111 Chinese cities. Sustain Cities Soc 63(September): 102493
Yilanci V, Gorus MS (2020) Does economic globalization have predictive power for ecological footprint in MENA counties? A panel causality test with a Fourier function. Environ Sci Pollut Res 27(32):40552-40562

Yin XS, Hussein J (2021) The implication of technological innovation and tourism development on FDI-growth-environment nexus in Association of Southeast Asian countries: a simultaneity modeling analysis. Energy Sources, Part B: Economics, Planning, and Policy 16(9):878-902

Zafar MW, Zaidi SAH, Khan NR, Mirza FM, Hou F, Kirmani SAA (2019) The impact of natural resources, human capital, and foreign direct investment on the ecological footprint: The case of the United States. Res Policy 63:101428

Zhang, L., Lin, X., Leng,L., \& Zeng, Y. (2021). Spatial distribution of rural population from a climate perspective: Evidence from Jiangxi Province in China. PLoS One, 16(3): e0248078.

Publisher's note Springer Nature remains neutral with regard to jurisdictional claims in published maps and institutional affiliations. 